\title{
RIGHT VENTRICLE INVOLVEMENT IN PATIENTS WITH ACUTE ST ELEVATION MYOCARDIAL INFARCTION: IS ECHOCARDIOGRAPHY GOOD ENOUGH IN DIAGNOSING IT?
}

\author{
Žanna Pičkure ${ }^{1,2}$, Artem Kalinin ${ }^{1,2}$, and Aivars Lejnieks ${ }^{1,2}$ \\ ${ }^{1}$ Rìga East Clinical University Hospital, 2 Hipokrāta Str., Rīga, LV-1038, LATVIA \\ ${ }^{2}$ Rīga Stradinš̌ University, 16 Dzirciema Str., Rīga, LV-1007, LATVIA \\ Corresponding author, zanna.pickure@gmail.com
}

Contributed by Aivars Lejnieks

\begin{abstract}
Right ventricle (RV) dysfunction in patients with ST elevation myocardial infarction (STEMI) is more common and important than previously considered. The aim of this study was to determine the incidence of RV involvement in acute STEMI by using advanced echocardiography (Echo) methods, such as RV longitudinal strain and three-dimensional (3D) ejection fraction, and to prove that RV involvement is not exclusive to right coronary artery damage in STEMI. The study group was formed of 73 patients aged 30 to 60 years with confirmed first-time acute STEMI and coronary angiography performed. Abnormality thresholds for standard and advanced Echo parameters in case of STEMI for predicted RV dysfunction were RV 3D ejection fraction < $49 \%$ and $R V$ free wall longitudinal strain $>-24.5 \%$. Using these abnormality thresholds it was possible to detect RV dysfunction in $60 \%$ of STEMI cases. The acquired results are close to the cardiac magnetic resonance data found in literature, which is the gold standard for determination of RV systolic function. RV involvement did not depend on the damaged coronary artery, as there was no association detected $(\mathrm{p}=0.09)$; therefore, $R V$ function should be assessed in every STEMI patient, and Echo is an effective method for this purpose.
\end{abstract}

Key words: ischemia, ultrasound, ejection fraction, longitudinal strain, right ventricle function, myocardial dysfunction.

\section{INTRODUCTION}

Worldwide, ischemic heart disease is the single most common cause of death and its frequency is increasing. Despite an improvement in the treatment tactics of acute STsegment elevation myocardial infarction (STEMI) in recent years and a decrease in mortality, it is still the cause of intra-hospital death in about $4-12 \%$ of patients, and oneyear mortality is around 10\% (Ibanez et al., 2018). For risk assessment following STEMI, early transthoracic echocardiography (Echo) is indicated for all patients prior to discharge from hospital (Ibanez et al., 2018). Unfortunately, current recommendations do not emphasise the incidence of right ventricle (RV) involvement in STEMI, merely considering this issue as a complication of left ventricle myocardial infarction. However, a great number of studies confirm that the RV involvement in the case of STEMI is associated with a threefold increase in cardiogenic shock, ventricular arrhythmias, atrioventricular blocks, and mechanical complication risk within intra-hospital and subsequent periods alike. The intra-hospital mortality rate is significantly higher among patients with inferior left ventricle myocardial infarction with RV involvement than without it (Mehta et al., 2001; Hamon et al., 2008) and RV involvement can be predicted using advanced Echo tools (Kanar et al., 2018). During the late post-infarction period, RV dysfunction, similar to left ventricle dysfunction, is an independent prognostic factor for all causes of mortality, cardiovascular mortality and heart failure development (Zornoff et al., 2002). Biventricular dysfunction increases the risk of mortality and heart failure even further (Skali et al., 2005).

It is critically important to recognise RV involvement in time, because compared to left ventricle myocardial infarc- 
tion, the treatment is different at several points, often the opposite. For example, in the case of extensive RV myocardial infarction, nitroglycerin and diuretics would be contraindicated. Although the systolic function of RV is reduced, occasionally the administration of additional fluids should be considered. Preference is given to restoring adequate heart rate and rhythm as well as inotropic agents.

Earlier, the two-dimensional (2D) Echo parameters were not as accurate, since RV systolic function was determined indirectly due to complex RV geometry. The gold standard for the RV ejection fraction (EF) determination is cardiac magnetic resonance imaging with known cost and availability limitations in cases of STEMI. However, advanced Echo techniques provide the ability to conduct direct and accurate evaluation of RV systolic function (Ishizu et al., 2017), useful not only for myocardial infarction, but also for patients with several other cardiac and non-cardiac pathologies (Dutta and Aronow, 2017). Early changes in RV function can be determined by 2D longitudinal strain (LS) measurements (Fig. 1). Also, Echo has been able to offer an alternative that is fast, cheap, non-invasive, and validated by magnetic resonance imaging, namely three-dimensional (3D) Echo, by which RV 3D-reconstruction provides a tool to directly determine volumes and EF (Fig. 2).

Our aim was to determine the incidence of RV involvement in acute STEMI by adding 3D Echo and myocardial LS evaluation to standard Echo. Additionally, we aimed to prove that RV involvement was not exclusive to right coro- nary artery (RCA) damage in STEMI. Moreover, our study allowed us to select the most informative Echo parameters of RV size and function for patients with acute STEMI.

\section{MATERIALS AND METHODS}

The prospective monocentric study was conducted at Rīga East Clinical University Hospital. The study was approved by the local Medical and Biomedical Research Ethics Committee. Every participant of the study had signed informed participation consent.

The study group was formed of 73 patients aged 30 to 60 years with confirmed first time acute STEMI and coronary angiography performed. Exclusion criteria were any of the following: haemodynamically unstable condition, noncoronary causes of the acute myocardial damage, any other confirmed heart or lung disease and prior pulmonary or cardiac surgery, heart rhythm disorders during the examination, chronic kidney disease, confirmed connective tissue or infiltrative diseases, pregnancy, and engagement in professional sports activities. Participants were excluded from the study if the quality of the acquired Echo images was poor.

The study protocol included clinical data, 12 lead ECG, results of coronary angiography and Echo data. Patients were divided into three groups based on the results of coronary angiography according to the acutely damaged artery: right coronary artery (RCA), left anterior descending artery (LAD) and left circumflex artery (LCX) group.

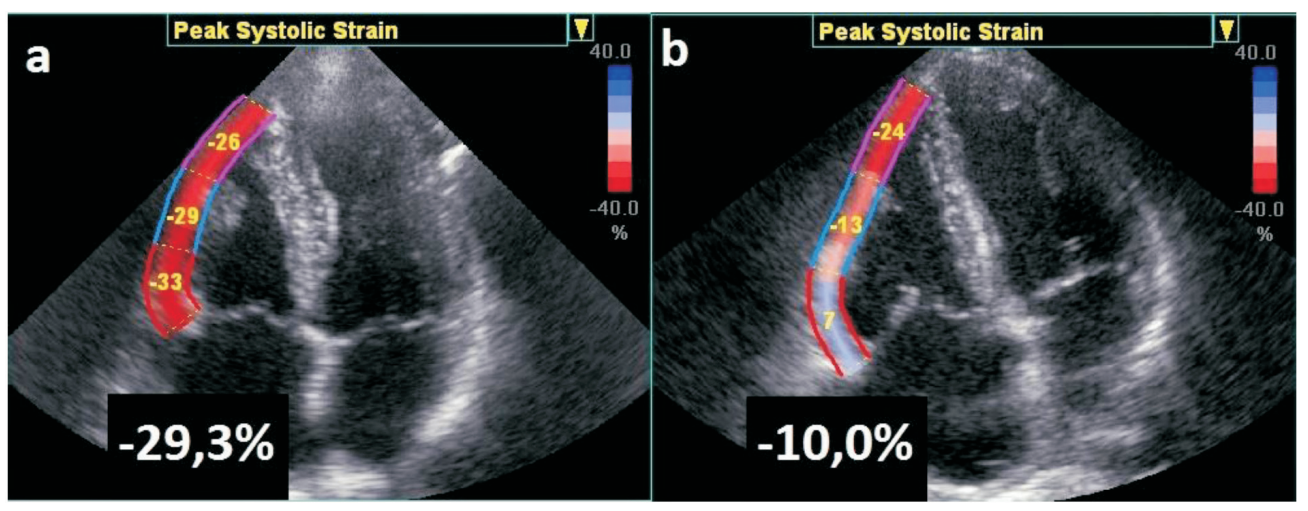

Fig. 1. Right ventricle free wall longitudinal strain: a. in a healthy individual; b. in a patient with ST elevation myocardial infarction.
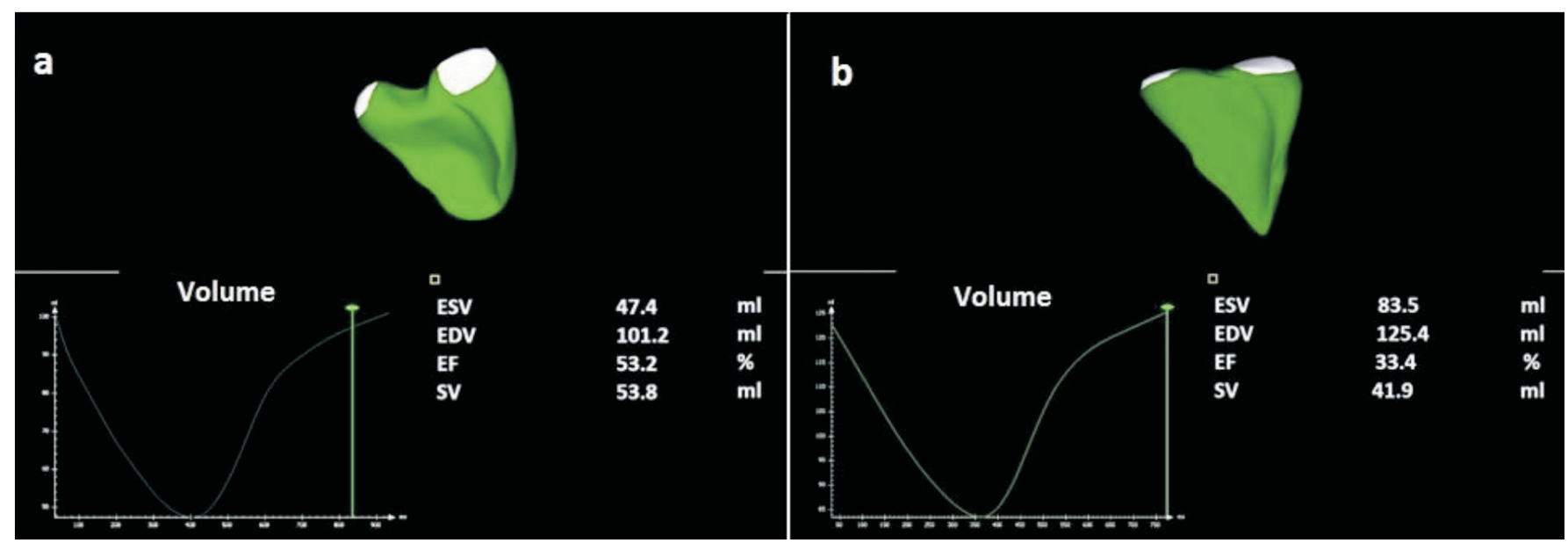

Fig. 2. Right ventricle volumes and ejection fraction: a. in a healthy individual; b. in a patient with ST elevation myocardial infarction. 
Echocardiography. All Echo examinations were performed by the same specialist using the same ultrasound machine Vivid E9 with M5S-D and 4V probes (General Electric Healthcare, United States) and one version of the software package. 2D, 3D Echo and Doppler imaging were performed and analysed according to the 2015 guidelines established by the American Society of Echocardiography and the European Association of Cardiovascular Imaging (Lang et al., 2015). The used abnormality thresholds for the $\mathrm{RV}$ measurements were also based on these guidelines.

For the assessment of the RV deformation, a RV focused four-chamber view was used. Quantitative evaluation of RV free wall total and segmental LS was performed with an ECHO PAC workstation (General Electric Healthcare, United States), using 2D speckle-tracking echocardiography.

To analyse RV volumes and the ejection fraction, real-time 3D full-volume image acquisition with consequent RV 3D reconstruction was performed using a commercially available software package (TomTec 4D-RV Analysis, Germany).

Echocardiography was performed between day 2 and day 4 after MI.

As a standard for determining RV systolic dysfunction for analysis, changes in the conventional 2D Echo parameters of the RV were accepted. RV systolic dysfunction was considered if any of the standard 2D function parameters (peak systolic velocity of tricuspid annulus, tricuspid annular plane systolic excursion or fractional area change) matched the abnormality criteria.

Statistical analysis. Descriptive statistics were used to characterise the studied groups. The arithmetic mean and standard deviation (SD) or the median and interquartile range (IQR; Q1-Q3) were used, depending on distribution. For the comparison of quantitative variables between the two groups, in the case of a normal distribution, an independent samples $t$ test was used and Cohen's d effect size was determined: small - 0.2-0.5; medium - 0.5-0.8; large $\geq 0.8$. For quantitative variables with a non-normal distribution, the Kruskal-Wallis $\mathrm{H}$ test was used, if more than two groups were compared. The Mann-Whitney U test was applied to assess differences between two groups, also determining the effect size $\mathrm{r}$ : small $-0.1-0.3$; medium $0.3-0.5$; high $\geq 0.5$.

In the case of nominal variables, percentages were determined. In comparison of these parameters in groups, the Pearson's chi-square test was used. The effect size Phi was determined for differences between the two groups: small $-0.1-0.3$; medium $-0.3-0.5$; high $\geq 0.5$. If there were more than two groups, the Cramer's V effect size was determined: small $-0.1-0.3$; medium $-0.3-0.5$; high $\geq 0.5$.

A $p$ value of less than 0.05 was considered significant.
Receiver Operating Characteristic (ROC) curve analysis was carried out to assess the diagnostic accuracy and to determine the diagnostic thresholds of the tested Echo parameters (3D RV volumes and EF, RV free wall and segmental LS). Evaluating the area under the curve (AUC), the following levels were used: $0.9<\mathrm{AUC}<1.0-$ excellent diagnostic accuracy; $0.8<$ AUC $<0.9$ - good; $0.7<$ AUC $<$ 0.8 - moderate; $0.6<$ AUC $<0.7$ - poor; and $0.5<$ AUC $<$ 0.6 - failed diagnostic method.

All statistical analyses were performed using the IBM SPSS Statistics 20.0 software package (IBM Corp., Armonk, NY, United States).

\section{RESULTS}

Characteristics of the group. The clinical characteristics of the group are presented in Table 1 . The study group included 73 patients (78\% males; mean [SD] age 52 [6] years, body mass index 27 [4.2], and 59\% smokers).

Echocardiographic assessment of the right ventricle. RV segmental systolic dysfunction by visual evaluation was determined in 19 (26\%) of 73 patients. A statistically significant $(p=0.02)$ association with a medium effect size (Cramer's $\mathrm{V}=0.32$ ) was found between an acutely damaged artery and presence of the RV dysfunction. In the case of RCA damage, RV segmental function impairment was found three times more frequently than in the LAD and LCX groups. By combining the visual assessment with RV dysfunction indices found by the standard 2D Echo, more cases of the RV involvement were detected in patients with acute STEMI - 26 (36\%). A statistically significant association was also confirmed between RV dysfunction and an acutely damaged artery $(p=0.02)$ with a medium effect size (Cramer's $\mathrm{V}=0.34$ ) (Table 2).

Following visual assessment in combination with both conventional 2D parameters and advanced study parameters (RV 3D EF and RV FW LS) in line with the abnormality thresholds laid down in the Recommendations of 2015

Table 1. Characteristics of the study group

\begin{tabular}{l|c|c}
\hline \multicolumn{1}{c|}{ Parameters } & $\begin{array}{c}\text { Patient group } \\
(\mathrm{n}=73)\end{array}$ & $95 \%$ CI \\
\hline Gender, Females/Male s & $16(22 \%) / 57(78 \%)$ & - \\
Age, years & $52.2[6.4]$ & $50.7-53.6$ \\
Mean [SD] & & \\
Height, m & $1.76[0.08]$ & $1.74-1.77$ \\
Mean [SD] & & \\
Weight, kg & $84.3[17.2]$ & \\
Mean [SD] & & $1.95-2.04$ \\
BSA, m ${ }^{2}$ & $1.99[0.22]$ & \\
Mean [SD] & & $26.0-28.0$ \\
BMI, kg/m & \\
Mean [SD] & $27.0[4.2]$ & \\
Smoker & & -
\end{tabular}

CI, confidence interval; BMI, body mass index; BSA, body surface area 
(Lang et al., 2015) for the RV dysfunction assessment, 31 cases $(42 \%)$ of RV involvement were found. The association between RV dysfunction and a damaged artery was also statistically significant in this case, but with a small effect size (Cramer's V $=0.27$ ).

As a standard for the determination of RV systolic dysfunction, changes in the traditional 2D RV Echo parameters were adopted for conducting ROC curve analysis. Real-time $3 \mathrm{D} R \mathrm{R}$ reconstruction was used to determine the RV volumes and EF. The RV volumes and systolic volume were indexed per body surface area. From the RV 3D volume parameters, RV end systolic volume (ESV), indexed ESV and EF form the statistically significant ROC curve $(p<0.001)$. Good RV involvement predictors were 3D RV indexed ESV ( $>28.8 \mathrm{ml} / \mathrm{m}^{2}$; AUC $=0.81$; sensitivity $77 \%$; and specificity $77 \%)$, and 3D RV EF $(<49 \%$; AUC = 0.88; sensitivity $73 \%$; and specificity $78 \%$ ) (Table 3 ).

All RV strain parameters represent statistically significant ROC curves $(p<0.001)$ for RV systolic dysfunction detection in patients with STEMI of any localisation. Excellent predictors were RV free wall LS ( $>-24.5 \%$; AUC $=0.95$; sensitivity $88 \%$; and specificity $89 \%$ ) and RV free wall mid segment LS (> -27.5\%; AUC = 0.92; sensitivity 88\%; and specificity $86 \%$ ). The other parameters represented good diagnostic models $(0.8 \leq$ AUC $\leq 0.9)$ (Table 4).

Taking into account the newly acquired cut-off levels of the studied parameters, i.e. RV 3D EF and RV free wall LS, and combining them with visual assessment and diagnostics according to standard parameters, RV involvement was found in $44(60 \%)$ patients with STEMI. The association between RV dysfunction and a damaged coronary artery (RCA, LAD or LCx), in this case, was not statistically significant $(p=0.09)$.

Analysis of the standard 2D echocardiographic parameters of the right ventricle in the groups according to the presence of right ventricle systolic dysfunction. Cut-off levels of the RV 3D EF and RV free wall LS, adjusted according to the study results, were used to divide patient groups in different ways depending on the presence of RV systolic dysfunction. Standard 2D Echo RV parameters were analysed. A statistically significant difference between patient groups with and without RV dysfunction was found for right atrium volume index, $\mathrm{RV}$ basal diameter, $\mathrm{RV}$ mid-cavity diameter, RV length, tricuspid annular plane

Table 2. RV dysfunction frequency in patient groups formed according to acutely damaged artery

\begin{tabular}{|c|c|c|c|c|c|}
\hline & \multicolumn{3}{|c|}{ Acutely damaged artery } & \multirow[t]{2}{*}{ Total } & \multirow{2}{*}{$\begin{array}{l}p \text { value / } \\
\text { effect size }\end{array}$} \\
\hline & $\begin{array}{c}\text { RCA } \\
(\mathrm{n}=34) \\
\end{array}$ & $\begin{array}{c}\text { LAD } \\
(\mathrm{n}=30)\end{array}$ & $\begin{array}{c}\text { LCx } \\
(n=9) \\
\end{array}$ & & \\
\hline \multicolumn{6}{|c|}{ By visual assessment } \\
\hline Present, n $(\%)$ & $14(41.2)$ & $4(13.3)$ & $1(11.1)$ & $19(26)$ & $0.02 / 0.32$ \\
\hline Absent, n $(\%)$ & $20(58.8)$ & $26(86.7)$ & $8(88.9)$ & $54(74)$ & \\
\hline \multicolumn{6}{|c|}{ By visual assessment and RV dysfunction detected by conventional parameters } \\
\hline Present, n $(\%)$ & $18(52.9)$ & $6(20)$ & $2(22.2)$ & $26(36)$ & $0.02 / 0.34$ \\
\hline Absent, n (\%) & $16(47.1)$ & $24(80)$ & $7(77.8)$ & $47(64)$ & \\
\hline
\end{tabular}

By visual assessment + RV dysfunction by conventional parameters + RV dysfunction by advanced parameters in compliance with the current recommendations

$\begin{array}{lllll}\text { Present, n (\%) } & 19(55.8) & 8(26.7) & 4(44.4) & 31(42) \\ \text { Absent, n (\%) } & 15(44.2) & 22(73.3) & 5(55.6) & 42(58)\end{array}$

$\overline{\mathrm{LAD} \text {, left anterior }}$ descending artery; LCx, left circumflex artery; RCA, right coronary artery; RV, right ventricle

Table 3. Receiver operating characteristic curve analysis of RV 3D parameters used in the RV dysfunction diagnostics in patients with STEMI

\begin{tabular}{|c|c|c|c|c|c|c|c|}
\hline RV parameter & AUC $(95 \% \mathrm{CI})$ & $p$ value & Cut-off value & $\mathrm{Se} \%(95 \% \mathrm{CI})$ & $\mathrm{Sp} \%(95 \% \mathrm{CI})$ & PPV \% $(95 \%$ CI $)$ & NPV \% $(95 \% \mathrm{CI})$ \\
\hline 3D RV EDV, ml & $0.63(0.48-0.77)$ & 0.08 & - & - & - & - & - \\
\hline 3D RV ESV, ml & $0.79(0.68-0.91)$ & $<0.001$ & 56.3 & $73(50-89)$ & $73(61-83)$ & $44(34-56)$ & $90(82-95)$ \\
\hline 3D RV SV, ml & $0.62(0.48-0.75)$ & 0.1 & - & - & - & - & - \\
\hline 3D RV EDV ind, $\mathrm{ml} / \mathrm{m}^{2}$ & $0.61(0.47-0.75)$ & 0.12 & - & - & - & - & - \\
\hline 3D RV ESV ind, $\mathrm{ml} / \mathrm{m}^{2}$ & $0.81(0.7-0.93)$ & $<0.001$ & 28.8 & $77(55-92)$ & $77(66-86)$ & $50(38-62)$ & $92(84-96)$ \\
\hline 3D RV SI, $\mathrm{ml} / \mathrm{m}^{2}$ & $0.68(0.55-0.80)$ & 0.01 & - & - & - & - & - \\
\hline 3D RV EF, \% & $0.88(0.79-0.96)$ & $<0.001$ & 49.0 & $73(50-89)$ & $78(67-87)$ & $50(38-62)$ & $91(83-95)$ \\
\hline
\end{tabular}

AUC, area under the curve; CI, confidence interval; EDV, end diastolic volume; EF, ejection fraction; ESV, end systolic volume; ind, indexed; NPV, negative predictive value; PPV, positive predictive value; RV, right ventricle; Se, sensitivity; SI, stroke volume index; Sp, specificity; STEMI, ST elevation myocardial infarction; SV, stroke volume 
Table 4. Receiver operating characteristic curve analysis of RV LS parameters used in the RV dysfunction diagnostics in patients with STEMI

\begin{tabular}{|c|c|c|c|c|c|c|c|}
\hline $\begin{array}{c}\mathrm{RV} \\
\text { parameter }\end{array}$ & $\begin{array}{c}\text { AUC } \\
(95 \% \mathrm{CI})\end{array}$ & $\begin{array}{c}p \\
\text { value }\end{array}$ & $\begin{array}{c}\text { Cut-off } \\
\text { value }\end{array}$ & $\begin{array}{c}\mathrm{Se} \% \\
(95 \% \mathrm{CI})\end{array}$ & $\begin{array}{c}\mathrm{Sp} \% \\
(95 \% \mathrm{CI})\end{array}$ & $\begin{array}{c}\text { PPV\% } \\
(95 \% \mathrm{CI})\end{array}$ & $\begin{array}{l}\text { NPV \% } \\
(95 \% \mathrm{CI})\end{array}$ \\
\hline $\begin{array}{l}\text { RV FW LS, } \\
\%\end{array}$ & $\begin{array}{c}0.95 \\
(0.89-1.0)\end{array}$ & $<0.001$ & 24.5 & $\begin{array}{c}88 \\
(70-98)\end{array}$ & $\begin{array}{c}89 \\
(80-95)\end{array}$ & $\begin{array}{c}74 \\
(60-85)\end{array}$ & $\begin{array}{c}96 \\
(89-99)\end{array}$ \\
\hline $\begin{array}{l}\text { RV FW basal LS, } \\
\%\end{array}$ & $\begin{array}{c}0.88 \\
(0.79-0.96)\end{array}$ & $<0.001$ & 26.5 & $\begin{array}{c}76 \\
(55-85)\end{array}$ & $\begin{array}{c}76 \\
(65-85)\end{array}$ & $\begin{array}{c}51 \\
(40-63)\end{array}$ & $\begin{array}{c}91 \\
(83-95)\end{array}$ \\
\hline $\begin{array}{l}\text { RV FW mid LS, } \\
\%\end{array}$ & $\begin{array}{c}0.92 \\
(0.84-0.99)\end{array}$ & $<0.001$ & 27.5 & $\begin{array}{c}88 \\
(69-97)\end{array}$ & $\begin{array}{c}86 \\
(76-93)\end{array}$ & $\begin{array}{c}67 \\
(53-78)\end{array}$ & $\begin{array}{c}96 \\
(88-98)\end{array}$ \\
\hline $\begin{array}{l}\text { RV FW apical LS, } \\
\%\end{array}$ & $\begin{array}{c}0.88 \\
(0.80-0.95)\end{array}$ & $<0.001$ & 22.0 & $\begin{array}{c}85 \\
(65-96)\end{array}$ & $\begin{array}{c}74 \\
(62-83)\end{array}$ & $\begin{array}{c}52 \\
(42-62)\end{array}$ & $\begin{array}{c}93 \\
(85-97)\end{array}$ \\
\hline
\end{tabular}

AUC, area under the curve; CI, confidence interval; FW, free wall; LS, longitudinal strain; NPV, negative predictive value; PPV, positive predictive value; $\mathrm{RV}$, right ventricle; Se, sensitivity; Sp, specificity; STEMI, ST elevation myocardial infarction

systolic excursion, fractional area change and pulmonary artery acceleration time. The most important of these was fractional area change (effect size $=0.58$, large), RV mid-cavity diameter and tricuspid annular plane systolic excursion (medium effect size, 0.31 and 0.37 , respectively) (Table 5).

\section{DISCUSSION}

With the development of new Echo methods, RV non-invasive assessment has become more informative, more accurate, overcoming the difficulties caused by its anatomical structure and positioning. This has enabled to take a closer look at changes in RV size and function in the case of various pathologies. Within this study, particular emphasis was given to RV systolic dysfunction in the case of acute STEMI.

The most appropriate standard parameters used for determining RV dysfunction were FAC $(p<0.001$; effect size $=$ 0.58 , large $)$ and TAPSE $(p=0.002$; effect size $=0.37$, medium). Median FAC and median TAPSE in patients with RV dysfunction proved to be higher than the abnormality threshold given in ASE/EACVI 2015 Recommendations for Cardiac Chamber Quantification by Echocardiography in Adults (Lang et al., 2015). In the case of FAC, it was $41 \%$ versus the $35 \%$ threshold specified in the guidelines, whereas in the case of TAPSE - $20 \mathrm{~mm}$ versus the $17 \mathrm{~mm}$ threshold. However, it should be kept in mind that the study group was subject to an age limit of up to 60 years according to the inclusion criteria, which may have affected the results obtained. Likewise, it should also be taken into account that the accuracy of both indicators in the assessment of RV systolic function had certain limitations, as measurements were made over one plane and were affected by the left ventricle. However, the most important reason for the difference between the obtained values and the guidelines for the specified abnormality threshold was that by breaking down the patients according to the presence of RV dysfunction, the RV longitudinal strain, which changed faster than the standard 2D Echo parameters, was used as a criterion.

The current ASE/EACVI recommendations of 2015 also set out the thresholds for advanced parameters for RV dysfunc-
Table 5. RV standard Echo parameters in patients with STEMI according to the presence of RV dysfunction

\begin{tabular}{|c|c|c|c|}
\hline $\begin{array}{c}\text { Right heart } \\
\text { parameter }\end{array}$ & $\begin{array}{c}\text { RV } \\
\text { dysfunction }\end{array}$ & $\begin{array}{l}\mathrm{Me}[\mathrm{IQR}] \\
(\min -\max )\end{array}$ & $\begin{array}{l}p \text { value / } \\
\text { effect size }\end{array}$ \\
\hline \multirow[t]{2}{*}{$\mathrm{RAVI}, \mathrm{ml} / \mathrm{m}^{2}$} & - present & $19[8] ;(7-45)$ & $0.03 / 0.25$ \\
\hline & - absent & 17 [6]; (10-27) & \\
\hline \multirow[t]{2}{*}{ RVOT sax, mm } & - present & 34 [6]; (25-44) & $0.11 / 0.18$ \\
\hline & - absent & 33 [5]; (25-43) & \\
\hline \multirow[t]{2}{*}{ RVD basal, mm } & - present & 36 [5]; (25-52) & $0.02 / 0.28$ \\
\hline & - absent & 34 [4]; (28-42) & \\
\hline \multirow[t]{2}{*}{ RVD mid, mm } & - present & 26 [7]; (15-39) & $0.006 / 0.31$ \\
\hline & - absent & $23[5] ;(16-31)$ & \\
\hline \multirow[t]{2}{*}{$\mathrm{RV} \mathrm{L}, \mathrm{mm}$} & - present & 77 [10]; (58-93) & $0.04 / 0.24$ \\
\hline & - absent & 73 [8]; (59-84) & \\
\hline \multirow[t]{2}{*}{ TAPSE, mm } & - present & $20[5] ;(10-27)$ & $0.002 / 0.37$ \\
\hline & - absent & 22 [4]; (14-29) & \\
\hline \multirow[t]{2}{*}{$\mathrm{FAC}, \%$} & - present & 41 [12]; (15-82) & $<0.001 / 0.58$ \\
\hline & - absent & $50[8] ;(37-62)$ & \\
\hline \multirow[t]{2}{*}{ PA ACT, ms } & - present & 112 [33]; (66-177) & $0.04 / 0.24$ \\
\hline & - absent & 123 [27]; (82-162) & \\
\hline \multirow[t]{2}{*}{$\mathrm{TR} V \max , \mathrm{m} / \mathrm{s}$} & - present & $2.41[0.3] ;(1.9-3.3)$ & $0.51 / 0.07$ \\
\hline & - absent & $2.35[0.6] ;(1.8-3.4)$ & \\
\hline \multirow[t]{2}{*}{ RVSP, $\mathrm{mmHg}$} & - present & 27.5 [10.0]; (17.5-55.0) & $0.47 / 0.08$ \\
\hline & - absent & $30.0[10.0] ;(17.5-47.5)$ & \\
\hline \multirow[t]{2}{*}{ TA S' V, cm/s } & - present & $12[5] ;(5-21)$ & $0.73 / 0.04$ \\
\hline & - absent & 13 [3]; (8-18) & \\
\hline
\end{tabular}

FAC, fractional area change; PA ACT, pulmonary artery acceleration time; RAVI, right atrium volume index; RVD, right ventricle diameter; RVOT, right ventricle outflow tract; RVSP, right ventricular systolic pressure; TA, tricuspid annulus; TAPSE, tricuspid annular plane systolic excursion; TR, tricuspid regurgitation

tion, but it should be noted that they are not abnormality specific. In 3D RV EF it is $<45 \%$, while in RV free wall LS it is $>-20 \%$ (Lang et al., 2015)). Within this study, 3D RV volume and LS parameters were analysed in patients in the STEMI age group for up to 60 years. As a standard in the determination of the RV systolic dysfunction, visual 
changes, and changes in traditional Echo parameters, were adopted. We observed that 3D RV volume indices indexed 3D RV ESV and 3D RV EF had good diagnostic value with satisfactory sensitivity and specificity when determining $\mathrm{RV}$ involvement in the case of STEMI. Indexed ESV $<28.8$ $\mathrm{ml} / \mathrm{m}^{2}$ and $\mathrm{EF}<49 \%$ best predicted RV systolic dysfunction. While the recommendations do not provide thresholds for the detection of abnormal changes in 3D RV volumes, 3D RV EF appeared to be $4 \%$ higher than the indicated pathological level. This is partly explained by the relatively younger group of patients involved in the study.

Changes in RV strain parameters showed better diagnostic value compared to 3D RV volumes and EF. This is not surprising, bearing in mind that RV systolic function is mainly provided by longitudinal contraction, and RV LS responds to a pathological condition with a decrease faster than in volume. Thereby, LS decrease alongside with reduced EF will show more severe RV systolic dysfunction than isolated RV LS changes. All RV LS parameters studied formed good or excellent statistically significant models for detection of RV systolic dysfunction in STEMI.

Excellent diagnostic models were total RV free wall LS with a threshold of $-24.5 \%, 88 \%$ sensitivity and $89 \%$ specificity, and RV free wall mid-segment LS with a threshold of $-27.5 \%, 88 \%$ sensitivity, and $86 \%$ specificity. As in the case of 3D RV EF, the obtained cut-off level for RV free wall LS was $4.5 \%$ higher than that provided in the 2015 recommendations, but coincides directly with the norm lower threshold (mean [SD] normal LS - 29\% [4.5]) (Lang et al., 2015). Nevertheless, when making a comparison between the obtained RV free wall LS threshold and the one determined by expert opinion in 2017 on the standardisation of the Echo protocol with modification of guidelines of 2015 , the difference was already significantly smaller $-1.5 \%$, as the new recommended threshold for diagnosing the pathology was $23 \%$ (Galderisi et al., 2017). In general, this indicates the accuracy and reliability of measurements performed within the framework of the study.

Pursuant to the RV 3D volume and LS analysis conducted within the study, patients were re-divided into groups with RV systolic dysfunction and without it, in addition to visual imaging and standard Echo parameters using 3D RV EF and RV free wall LS thresholds found in this study. As a result, $\mathrm{RV}$ involvement was discovered in 44 patients, representing $60 \%$ of the patient group. Such a finding is much closer to autopsy research data that shows the highest rate of RV involvement, up to $84 \%$ in the case of myocardial infarction, among all RV research methods (Andersen et al., 1987), including the gold standard - cardiac magnetic resonance imaging (47-65\%) (Jensen et al., 2010). Applying the new thresholds specified in 3D RV EF and RV free wall LS, involvement of RV, according on the damaged artery showed no statistically significant association. This indicates the possibility of RV systolic dysfunction in STEMI of any localisation.

\section{LIMITATIONS OF THE STUDY}

The first and foremost constraint of the study was the unavailability of cardiac magnetic resonance imaging for acute STEMI patients involved in the study. It would be necessary to verify the 3D RV EF and RV free wall LS new thresholds for detecting RV dysfunction.

The number of patients should also be considered among the restrictions. Overall, the number of participants included in the study was sufficient. However, dividing the patients into subgroups in the statistical analysis, the number of patients in the LCx group was the lowest, which may have affected the accuracy of the results. In the patient group, all participants were accepted one by one according to the selection criteria, rather than by the localisation of STEMI. The LCx pool infarctions proved to be the least common.

Echo visualisation represents a limitation to any investigation method based on ultrasound use. Poor Echo visualisation of heart structures was a criterion for exclusion in the study, but imaging of moderate quality could also partially have affected the accuracy of the measurements. On the other hand, by doing so, the study becomes more realistic and is closer to everyday practice.

\section{CONCLUSIONS}

Based on the results of the study, depending on the method of evaluating RV dysfunction, its involvement in STEMI was observed in 26-60\% of cases. The least RV dysfunction was identified by visual assessment alone. The highest percentage of involvement was determined by combining visual assessment with standard 2D Echo methods and advanced parameters such as 3D RV EF and RV free wall LS, using the higher thresholds determined in this study. Modern Echo can provide much closer results to the gold standard — cardiac magnetic resonance imaging and autopsy data.

Changes in RV function, based on both standard 2D Echo parameters and 3D RV EF and RV free wall LS, can be observed if any of the three coronary arteries is damaged, since the association between RV dysfunction and damaged coronary artery (RCA, LAD or LCx), in this case, was not statistically significant.

Based on the results of the study conducted, it was possible to identify the most useful of the RV assessment parameters that should be used in daily practice in patients with STEMI. These include visual assessment of RV segmental and global systolic function, tricuspid annular plane systolic excursion, fractional area change, RV mid-cavity diameter, RV free wall LS, and 3D RV EF.

\section{REFERENCES}

Andersen, H. R., Falk, E., Nielsen, D. (1987). Right ventricular infarction: frequency, size and topography in coronary artery disease: A prospective study comprising 107 consecutive autopsies from a coronary care unit. $J$. Amer. Coll. Cardiol., 10 (6), 1223-1232. 
Dutta, T., Aronow, W. S. (2017). Echocardiographic evaluation of the right ventricle: Clinical implications. Clin. Cardiol., 40 (8), 542-548.

Galderisi, M., Cosyns, B., Edvardsen, T., Cardim, N., Delgado, V., Di Salvo, G., Donal, E., Sade, LE., Ernande, L., Garbi et al. (2017). Standardization of adult transthoracic echocardiography reporting in agreement with recent chamber quantification, diastolic function, and heart valve disease recommendations: An expert consensus document of the European Association of Cardiovascular Imaging. Eur. Heart J. Cardiovasc. Imaging, 18 (12), 1301-1310.

Hamon, M., Agostini, D., Le Page, O., Riddell, J. W. (2008). Prognostic impact of right ventricular involvement in patients with acute myocardial infarction: Meta-analysis. Crit. Care Med., 36 (7), 2023-2033.

Ibanez, B., James, S., Agewall, S., Antunes, M. J., Bucciarelli-Ducci, C., Bueno, H., Caforio, A. L. P., Crea, F., Goudevenos, J. A., Halvorsen, S. et al. (2018). 2017 ESC Guidelines for the management of acute myocardial infarction in patients presenting with ST-segment elevation: The Task Force for the management of acute myocardial infarction in patients presenting with ST-segment elevation of the European Society of Cardiology (ESC). Eur. Heart J., 39 (2), 119-177.

Ishizu, T., Seo, Y., Atsumi, A., Tanaka, Y. O., Yamamoto, M., MachinoOhtsuka, T., Horigome, H., Aonuma, K., Kawakami, Y. (2017). Global and regional right ventricular function assessed by novel three-dimensional speckle-tracking echocardiography. J. Amer. Soc. Echocardiogr., 30 (12), 1203-1213.

Jensen, C. J., Jochims, M., Hunold, P., Sabin, G. V., Schlosser, T., Bruder, O. (2010). Right ventricular involvement in acute left ventricular myocardial infarction: Prognostic implications of MRI findings. AJR Amer. J. Roentgenol., 194 (3), 592-598.

Kanar, B. G, Tigen, M. K., Sunbul, M., Cincin, A., Atas, H., Kepez, A., Ozben, B. (2018). The impact of right ventricular function assessed by 2-dimensional speckle tracking echocardiography on early mortality in patients with inferior myocardial infarction. Clin. Cardiol., 41 (3), 413-418.

Lang, R. M., Badano, L. P., Mor-Avi, V., Afilalo, J., Armstrong, A., Ernande, L., Flachskampf, F. A., Foster, E., Goldstein, S. A., Kuznetsova, T. et al. (2015). Recommendations for cardiac chamber quantification by echocardiography in adults: An update from the American Society of Echocardiography and the European Association of Cardiovascular Imaging. J. Amer. Soc. Echocardiogr., 28 (1), 1-39.

Mehta, S. R., Eikelboom, J. W., Natarajan, M. K., Diaz, R., Yi, C., Gibbons, R. J., Yusuf, S. (2001). Impact of right ventricular involvement on mortality and morbidity in patients with inferior myocardial infarction. J. Amer. Coll. Cardiol., 37 (1), 37-43.

Skali, H., Zornoff, L. A., Pfeffer, M. A., Arnold, M. O., Lamas, G. A., Moyé, L. A., Plappert, T., Rouleau, J. L., Sussex, B. A., Sutton, M. St J., Braunwald, E., Solomon, S. D. (2005). Prognostic use of echocardiography 1 year after a myocardial infarction. Amer. Heart J., 150 (4), 743-749.

Zornoff, L. A., Skali, H., Pfeffer, M. A., Sutton, M. St J., Rouleau, J. L., Lamas, G. A., Plappert, T., Rouleau, J. R., Moyé, L. A., Lewis, S. J., Braunwald, E., Solomon, S. D. (2002). Right ventricular dysfunction and risk of heart failure and mortality after myocardial infarction. J. Amer. Coll. Cardiol., 39 (9), 1450-1455.

\section{LABĀ KAMBARA DISFUNKCIJA PACIENTIEM AR AKŪTU ST ELEVĀCIJU MIOKARDA INFARKTU: VAI EHOKARDIOGRĀFIJA SPĒJ TO ATKLĀT?}

Labā kambara (LK) disfunkcija pacientiem ar ST elevāciju miokarda infarktu (STEMI) ir biežāka un nopietnāka, nekā ierasts domāt. Pētījuma mērkis bija noteikt LK iesaistīšanās incidenci pacientiem ar akūtu STEMI, pielietojot modernas ehokardiogrāfijas metodes, tādas kā LK gareniskās deformācijas un trīsdimensiju izsviedes frakcijas noteikšana. Tikpat svarīgs mērḳis bija pierādīt, ka LK disfunkcija ir iespējama ne tikai labās koronārās artērijas, bet arī pārējo sirds artēriju akūta bojājuma gadījumā. Pētījuma grupā tika iekḷauti 73 pacienti vecumā no 30 līdz 60 gadiem ar apstiprinātu pirmreizējo akūto STEMI, kuriem tika veikta koronarogrāfija. Tika precizēti standartparametru un moderno parametru sliekšṇi patoloǵisku izmaiṇu noteikšanai pacientiem ar STEMI. LK trīsdimensiju izsviedes frakcija < 49\% un LK brīvās sienas gareniskā deformācija > -24,5 \% vislabāk paredzēja LK disfunkciju. Pielietojot šos robežlielumus, bija iespējams noteikt LK disfunkciju 60\% gadījumu. Šie dati līdzinās publicēto pētījumu rezultātiem, kur LK disfunkcijas noteikšanai tika pielietots diagnostikas "zelta standarts" - sirds magnētiskā rezonanse. Statistiski ticama asociācija starp LK iesaistī̌sanos un bojāto asinsvadu netika atrasta $(p=$ 0,09), tāpēc LK funkcija jānosaka katra STEMI pacienta gadījumā neatkarīgi no miokarda infarkta lokalizācijas. Modernā ehokardiogrāfija ir efektîvs rīks LK izvērtēšanai. 